\title{
Kukutxeztula: «gainditutako» gaitz baten itzulera
}

\author{
(Pertussis: return of a «surpassed» disease)
}

\author{
Jone Amuategi Aulestiarte*,1, Asier Benito-Vicente ${ }^{1}$, Kepa B. Uribe ${ }^{2}$, \\ César Martín Plágaro ${ }^{1}$, Helena Ostolaza Etxabe ${ }^{1}$ \\ ${ }^{1}$ BIOFISIKA, Basque Center For Biophysics \\ (UPV/EHU-CSIC), Sarriena auzoa, 48940 Leioa \\ ${ }^{2}$ Center for Cooperative Research in Biomaterials (CIC biomaGUNE)
}

\begin{abstract}
LABURPENA: Arnasbideetako infekzioek heriotza tasa altuak eragiten dituzte munduan, COVID-19 birusa izanik azken urteetako adibiderik argiena. Hala ere, ez da libre dabilen patogeno bakarra eta berrikuspen honetan Bordetella pertussis bakterio patogenoak eragindako kukutxeztulaz arituko gara. Kukutxeztula arnasbideen infekzio larri eta kutsakorra da, bertako jariakinekin edota listu tantekin kontaktua izatean transmititzen dena. Helduetan arrisku berezirik ez duten sintomak eragiten dituen arren (etengabeko eztul gertakariak, arnasteko zailtasuna edota sukarra, besteak beste), heriotza eragin dezake urte batetik beherako haurretan batez ere. Kukutxeztula fase goiztiar batean gainditu ez duten gaixoek bigarren mailako pneumonia bezalako konplikazioak garatu ditzakete, horixe izaten delarik kukutxeztulaz hiltzen diren gehienen arrazoi nagusia. Lehen txertoa garatu zenetik kontrolpean zegoela uste izan den arren, kalte handiak eragin ditu garapen bidean dauden herrialdeetan batez ere. Herrialde garatuetan ere badu bere inpaktua, eta 2011tik gaur arte Ipar Amerikan eta mendebaldeko Europan epidemia egoera zabaldu da. Berrikuspen honetan kukutxeztulari buruzko informazioaren eguneratze bat aurkezten da, B. pertussisek erabiltzen dituen hainbat mekanismo infekziosotan arreta jarriz. Mekanismo hauen oinarri molekularra ulertzeak lagundu dezake zeluletan gertatzen diren beste hainbat prozesuren ulerkeran, gaixotasunaren aurkako sendagai berrien garapenean edota biologia molekularreko tresna berrien garapenean.
\end{abstract}

HITZ GAKOAK: kukutxeztula, Bordetella pertussis, adenilato ziklasa toxina, toxina poro eragileak.

\begin{abstract}
Respiratory infections cause high mortality rates throughout the world, being the COVID-19 virus the clearest example in recent years. However, there are other several pathogens not fully controlled and in this review we will focus on whooping cough, the sickness caused by the pathogenic bacterium Bordetella pertussis. Whooping cough is a severe and contagious respiratory infection that is transmitted by coming into contact with local secretions or with saliva drops. Despite the symptoms are not of special risks for adults (continuous episodes of cough, difficulty breathing or fever), it can cause death especially in children younger than one year of age. Patients who have not overcome cough at an early stage may develop complications such as secondary pneumonia, which is the main cause of most who die with whooping cough. Although since the development of the first vaccine it has been considered to be under control, whooping cough has caused significant damage especially in developing countries. Surprisingly, it has also an impact on developed countries and since 2011 the epidemic has spread in North America and Western Europe. This review presents an update on whooping cough, focusing on the different infective mechanisms used by B. pertussis. Understanding of the molecular basis of these mechanisms may contribute to the understanding of other cellular processes, the development of new anti-disease drugs or the development of new molecular biology instruments.
\end{abstract}

KEYWORDS: whooping cough, Bordetella pertussis, adenylate cyclase toxin, pore forming toxins.

* Harremanetan jartzeko / Corresponding author: Jone Amuategi Aulestiarte. Biofisika, Basque Center For Biophysics (UPV/EHU-CSIC), Sarriena auzoa (48940 Leioa). - jamuategui001@ehu.eus - https://orcid.org/0000-0002-8734-7001.

Nola aipatu / How to cite: Amuategi Aulestiarte, Jone; Benito-Vicente, Asier; B. Uribe, Kepa; Martín Plágaro, César; Ostolaza Etxabe, Helena (2021). "Kukutxeztula: "gainditutako" gaitz baten itzulera»; Ekaia, 39, 2021, 61-78. (https://doi.org/10.1387/ekaia.21789).

Jasoa: 2020, ekainak 4; Onartua: 2020, urriak 2.

ISSN 0214-9001 - elSSN 2444-3255 / (c) 2021 UPV/EHU

(c) (i) (2) Obra hau Creative Commons Atribución 4.0 Internacional-en

lizentziapean dago 
Jone Amuategi Aulestiarte, Asier Benito-Vicente, Kepa B. Uribe, César Martín Plágaro, Helena Ostolaza Etxabe

\section{SARRERA}

Osasunaren Mundu Erakundeak (OMEk) argitaratutakoaren arabera, kardiopatia iskemikoa, garun hodiei loturiko eritasunak eta arnasbideetako infekzioak daude azken 15 urteetan heriotza tasarik altuenak eragin dituzten gaixotasunen artean. Gainera, arnasbideetako infekzioak dira mundu mailako gaixotasun kutsakorrik hilgarrienak. Esaterako, 2016. urtean 3 milioi pertsona hil ziren behe arnasbideetako (trakeako, bronkioetako, bronkioloetako edota albeoloetako) infekzioen ondorioz [1]. Arnasbideek bakterioei, bizitoki optimo bat eskaintzeaz gain, beste norbanako batzuk kutsatzeko aukera ere eskaintzen diete. Gainera, zenbait patogeno oportunistak arnasbideetako infekzioen ondoriozko egoera ahulak baliatu ditzakete bestelako gaixotasun inbaditzaileak sorrarazteko.

Arnasbideetako gaixotasunen artean, Bordetella pertussis patogenoak gizakietan kukutxeztula eragiten du, zenbait populaziorentzat infekzio larri eta kutsakorra izan daitekeena. Arnasbideetako jariakinekin edota listu tantekin kontaktu zuzena izatean transmititu daiteke. Eragindako sintomen larritasuna gaixoaren adinaren, immunitate-sistemaren erantzunaren eta bakterioaren barreiatze sistemikoaren araberakoa da. Helduen kasuan sintoma nahiko arruntak eragiten ditu: etengabeko eztul gertakari zakarrak, arnasa hartzeko zailtasuna, sukarra edota goragalea. Beraz, helduetan arrisku handirik ez duen arren, jaioberrietan apnea bezalako konplikazioak ohikoak dira. Gainera, bakterioak goi arnasbideetatik (sudurretik, sudur-barrunbetik, faringetik edota laringetik) behe arnasbideetara migratu dezake, bertan bronkitis nekrotikoa, albeoloetan kaltea edota hemorragia eraginez, besteak beste. Kasurik larrienetan, biriketako hipertentsioaren eta arnas gutxiegitasunaren ondorioz, heriotza eragin dezake [2]. Kukutxeztularen ondorioz hiltzen diren gaixoen \% 90 pneumonia bezalako konplikazioengatik hiltzen dira. Gaixotasunaren inkubazio aldia 9-10 egunekoa izaten da normalean, eta gehienez 6-20 egun bitartean iraun dezake. Katarroaren lehen bi asteetan bereziki kutsakorragoa da eta kasuen \% 90 etxekoen bitartez kutsatzen dira immunitate ezagatik [3].

Bordetella generoko beste zenbait espeziek gaitasuna dute gizakiak nahiz animaliak kutsatzeko: $B$. parapertussisek, $B$. holmesiik eta $B$. bronchisepticak, adibidez. B. parapertussisek eta B. homelsiik kukutxeztularen antzeko gaixotasunak eragiten dituzte gizakietan, nahiz eta sintomak arinagoak izaten diren. B. bronchisepticak, berriz, immunitate sistema ahula duten pertsonei, trauma-gaixoei edota peritonitisa dutenei erasotzen die [2]. Hala ere, Euskal Autonomia Erkidegoan (EAEn), behintzat, derrigorrezkoa $B$. pertussisen aurkako txertoa baino ez da [3].

Kukutxeztularen aurkako lehenengo txertoa Leila Daughtry-Denmark pediatrak garatu zuen 1930eko hamarkadan eta kimikoki edo bero bidez hildako B. pertussis zelula osoz, ingelesez Whole-Cell Vaccine (WCV), 
prestatuta zegoen [4]. Geroztik, haurtzaroan jasotako txertoei esker, herrialde garatuetan gaixotasunak eragindako heriotza tasa izugarri jaitsi da. Esaterako, 1980an AEBtan gaixotasunaren intzidentzia 100.000 biztanleko pertsona bakarrekoa zen. Hala ere, azken hamarkadetan kasu kopurua era kezkagarrian igo da, osasun zerbitzu publiko askoren arazo bihurtuz. Europari dagokionez, 2011z geroztik epidemia egoeran dagoela baieztatu dute [5]. Brasilen 2011tik 2014ra kasu kopurua bikoiztu egin zen eta beste herrialde askok ere kukutxeztul kasuen igoera jasaten ari direla jakinarazi dute: Australiak, Argentinak edo Kanadak, esate baterako [6]. Espainiari dagokionez, 2015ean intzidentziarik altuena EAEk izan zuen, urte horretan kasuen gorakada nabarmena gertatu zelarik (1. irudia), erregistratutako 100.000 biztanleko 91,67 kasurekin.

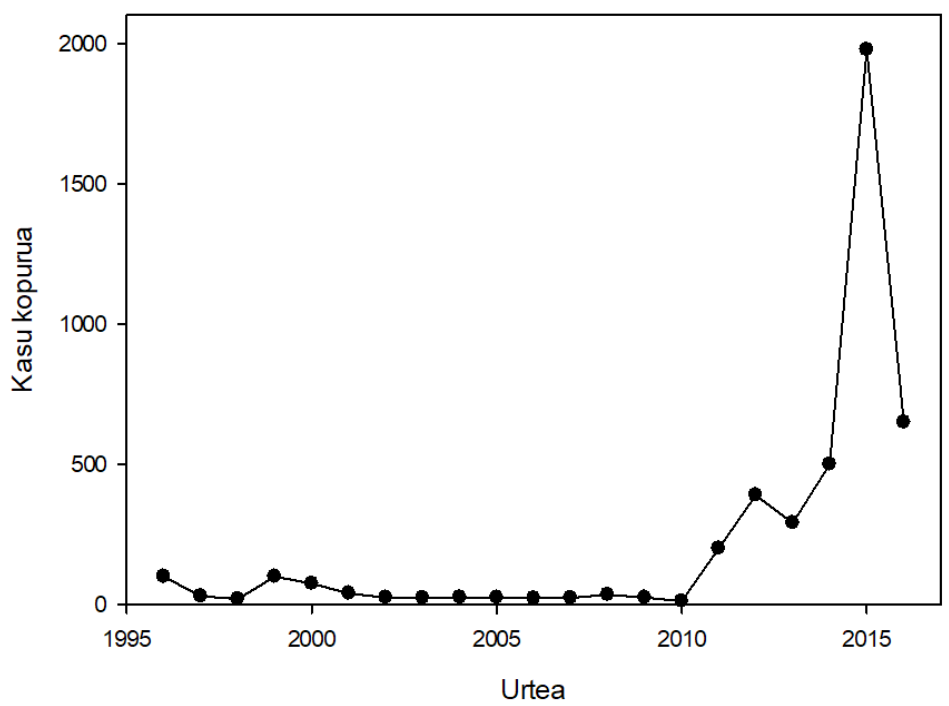

1. irudia. EAEko kukutxeztul kasu berrien eboluzioa 1996-2016 urteen artean. EDO erregistrotik eratorritako datuekin osatutako grafikoa [3].

\section{B.PERTUSSISEN BIRULENTZIA-FAKTOREAK}

B. pertussis bakterio Gram negatiboa eta derrigorrezko aerobioa da. 0.2-0.7 $\mu \mathrm{m}$ bitarteko neurria du eta kokobazilo itxura dauka. Kapsula eta pilien antzeko harizpiak ditu eta bere hazkuntza tenperatura optimoa $35-37^{\circ} \mathrm{C}$ artean finkatzen da [7]. Isolatu zenetik mugiezin eta ez-flagelatu moduan deskribatu den arren, duela gutxi flageloen antzeko egiturak adieraz ditzakela ikusi dute [8]. Hala ere, oraindik ez dago argi infekzioan zehar flageloa adierazteko gai den, ezta flageloak infekzioan eta transmisioan funtzio garrantzitsurik betetzen ote duten ere (2. irudia). 
Jone Amuategi Aulestiarte, Asier Benito-Vicente, Kepa B. Uribe, César Martín Plágaro, Helena Ostolaza Etxabe

B. pertussisek arnasbideen kolonizaziorako biofilmak eratzeko gaitasuna dauka. Horrez gain, gizakien goi arnasbideetako mukosarekiko afinitate espezifikoa du. Inbasio prozesuetan epitelioko zeluletara itsasten da eta epitelioko estalkia suntsitzen lagunduko dioten zenbait birulentzia-faktore jariatzen ditu (2. irudia). Itsatsi ostean, bakterioa biderkatuz joaten da eta ostalariaren defentsei (mukosako zilioen garbiketari, mikrobioen aurkako peptidoei eta hanturako zelulei) aurre egiten die. Horrenbestez, goi eta behe arnasbideak kaltetzen ditu. Beste mikroorganismo askorekin gertatzen den bezala, birulentzia-faktoreak bere patogenotasunerako tresna garrantzitsuak dira, immunitate-sistema saihesten laguntzen baitiote. Birulentzia-faktore horien erregulaziorako $B v g A S$ osagai biren bidezko erregulazio sistema profitatzen du [9]. Sistema honek inguruneko baldintzen arabera ehunka gene kontrolatzeko gaitasuna dauka. Esaterako: gainazaleko egiturak edota jariatze proteinak kodetzen dituztenak; ugaztun ostalaritik kanpo bizirauteko beharrezko faktoreak; zelularen metabolismoan, fisiologian edota erregulazio sistemetan parte hartzen duten entzimak [10]. B. pertussisen birulentziafaktore nagusiak gainazaleko proteinak eta jariatzen dituen toxinak dira.

\subsection{Gainazaleko proteinak}

Bakterioa arnasbideetako epiteliora itsas dadin ezinbestekoak dira gainazaleko proteinak. Gainera, ostalariaren erantzun immunea ere modulatzen dute, bakterioaren biziraupena ahalbidetuz. Horien artean hemaglutinina haritsua, ingelesez Filamentous Haemagglutinin Adhesin (FHA), nabarmendu genezake, Bordetella generoko adhesinarik garrantzitsuena baita. Adhesinak zelularen gainazaleko osagaiak dira, bakterioa beste zelula edo gainazal batzuetara itsastea ahalbidetuko dutenak. Hauez gain, pertaktinak ere itsaste prozesuetan parte hartzen du, neutrofiloak saihesten laguntzeaz gain [11]. Azkenik, lipopolisakaridoaren ekoizpenak bakterioak eragindako hantura murrizten laguntzen du. Izan ere, $B$. pertussisek sintetizatutako lipopolisakaridoari O-antigenoa falta zaio eta, beraz, gizakietan TLR4 hartzailedun immunitate-sistemako zelulak kitzikatzeko duen gaitasuna nahiko txikia da, honek hantura txikiagoa eragingo duelarik [12].

\subsection{Toxinak}

Toxinak dira organismo bizidunek sintetizatzen dituzten edota haien jarduera metabolikoen produktuak diren substantzia pozoitsuak. Ehunetan sartzen direnean toxikoak izaten dira eta normalean antigorputzen ekoizpena eragiten dute [13]. Hortaz, zelulak kaltetzen dituzten erremintak dira eta bizi-erreinu guztietan aurki daitezke, bakterioetatik hasi eta gizakietaraino. Toxina hitza oso kategoria zabala da; izan ere, tamaina eta forma anitzetakoak izan daitezke, kargaturiko atomoetatik hasita, hainbat proteinaz osatutako konplexuetaraino [14]. Aniztasun honek zelulak kaltetzeko 
mekanismo desberdinen garapenean badu zerikusia. Horri esker, substantzien toxikotasun maila ere asko aldatzen da [15]. B. pertussisen kasuan, Adenilato Ziklasa Toxina, ingelesez Adenylate Cyclase Toxin (ACT), eta Toxina Pertusikoa, ingelesez Pertussis Toxin (PT), arnasbideen kolonizaziorako ezinbestekoak dira. Bi hauez gain, trakeako zitotoxina eta toxina dermonekrotikoa ere aipa genitzake. Hala ere, berrikuspen honetan, egun ACTari buruz dakiguna bildu nahi izan da. Irakurleak gehiago jakin nahiko balu $B$. pertussisek jariatutako birulentzia-faktoreen inguruan, artikulu bukaerako [16] eta [17] oharretako artikuluak irakurtzera gonbidatzen dugu.
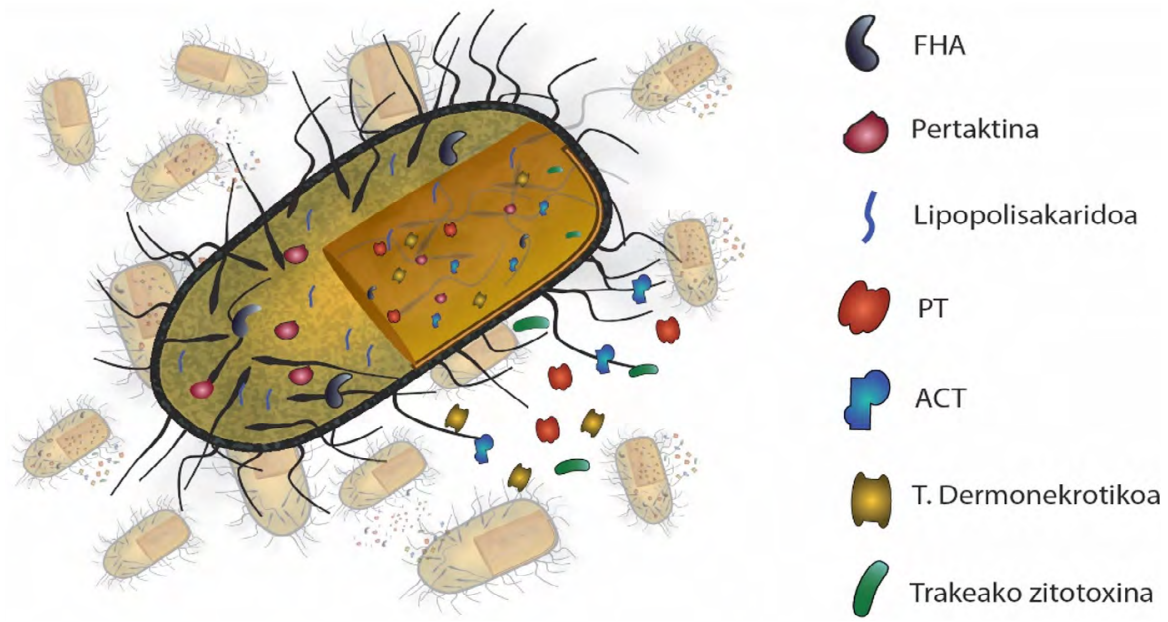

2. irudia. B. pertussis eta bere birulentzia-faktoreak. B. pertussisek inbasio prozesuan zehar hainbat birulentzia faktore baliatzen ditu: gainazaleko FHAk eta pertaktinak itsaste prozesuetan parte hartzen dute; PTa, ACTa, toxina dermonekrotikoa eta trakeako zitotoxina zelula ostalariarentzat toxikoak dira; eta lipopolisakaridoak hantura txikia eragiten du.

\section{ADENILATO ZIKLASA TOXINA (ACT)}

Aldez aurretik aipatu den bezala, ACTa da B. pertussisek jariatutako birulentzia-faktoreen artean garrantzitsuenetako bat. Arnas traktuko kolonizazioaren lehen etapetan funtsezkoa da, besteak beste, ostalariaren erantzun immunologikoa ahultzen duelako [18]. ACTak zelula ostalari desberdinetara lotzeko gaitasuna du, eritrozitoetatik hasita zelula epitelialetara, eta baita immunitate-sistemako hainbat zelulatara ere [19] [20] [21]. Gainera, mintz-egiturak, liposomak artean, iragazkor bihurtzeko gai ere bada [22]. Lotura ez-espezifikoez gain, ACTak CD11b/CD18 integrina hartzailea espezifikoki ezagutzen du [23]. Aipaturiko hartzailea immunitate sistemaren parte diren lerro mieloideko zelulek (neutrofiloek, zelula dendritikoek eta 
Jone Amuategi Aulestiarte, Asier Benito-Vicente, Kepa B. Uribe, César Martín Plágaro, Helena Ostolaza Etxabe

makrofagoek) adierazten dute gainazalean. Horrez gain, ACTa T zelulei lotzeko gai ere badela deskribatu da, horretarako, CD11a/CD18 zelula hartzailea erabiliz, nahiz eta zelula hauetan aktibitate zitotoxiko baxua duen [24].

ACTa 1706 aminoazidoz osatuta dago eta bere pisu molekularra $200 \mathrm{kDa}$ ingurukoa da. Egitura eta funtzio aldetik argi bereiz daitezkeen bi domeinuk osatzen dute: N-muturreko Adenilato Ziklasa (AC) domeinua eta C-muturreko RTX domeinu hemolitiko edo poro-eragilea (3. irudia). Bi domeinu hauen artean linker edo lotura-eskualdea deskribatu da [25].

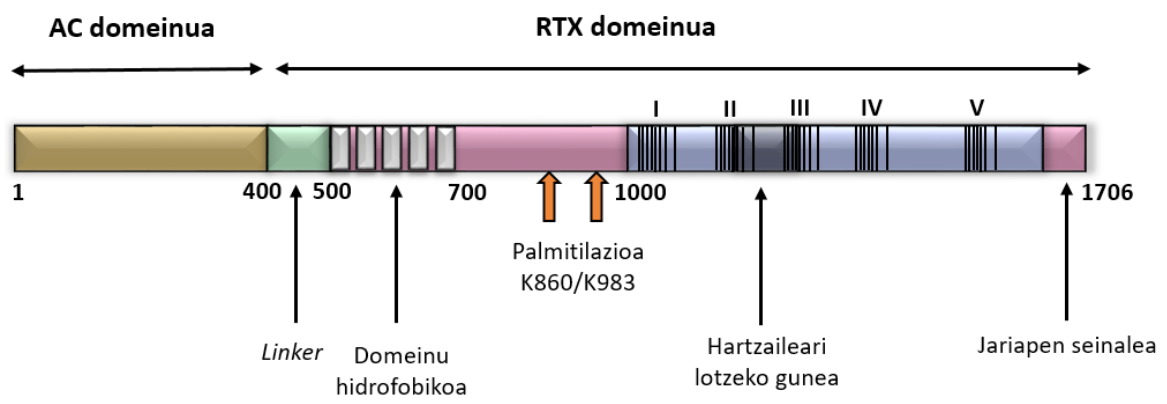

3. irudia. ACT toxinaren egitura. N-muturreko lehenengo 400 aminoazidoek Adenilato Ziklasa (AC) domeinua osatzen dute eta beste 1306 aminoazidoek RTX domeinu hemolitiko edo poro-eragilea. Bi domeinu hauen artean linker eskualdea deskribatu da, 400-500 aminoazidoen artean. Hartzaileari lotzeko gunea C-mutur aldean kokatzen da.

Bi funtzio horiei esker, intoxikaziorako mekanismo berezia erabiltzen du. Izan ere, bi aktibitate independenteek jarduera zitotoxikoa emendatzeko kooperazioan jarduten dute [26].

\subsection{Adenilato Ziklasa (AC) domeinuaren aktibitate katalitikoa}

Adenilato Ziklasa (AC) domeinuak zelula eukariotoen zitosolean adenosin monofosfato-3',5' ziklikoaren (cAMParen) kontrolik gabeko sintesia katalizatzen du, horretarako, zelula barneko adenosin trifosfatoa (ATP) erabiliz. cAMPak zelularen seinaleztapen prozesuak asaldatuko ditu, zenbait kasutan apoptosia eraginez. ACTa proteina termolabila da, hortaz, tenperatura jakin batetik gora aktibitatea gal dezake. Aktibitate katalitiko maximoa $30{ }^{\circ} \mathrm{C}$-tan, $\mathrm{pH}$ 7-8 tartean eta magnesioaren eta kalmodulinaren (CaMren) presentzian burutzen da [27]. CaM AC domeinuari lotzen zaion proteina bat da eta honi esker bere aktibitate katalitikoa izugarri emendatzen da [28].

AC domeinuak zitosoleko cAMPari eragin diezaion, mintz plasmatikoa zeharkatu beharko luke. Haren atzean ezkutatzen den mekanismo molekularra oraindik ezagutzen ez den arren, zuzenean zeharkatzen duela deskri- 
batu da. Onartuen dagoen translokazio eredua Bumba eta kideek proposatutakoa da (4. irudia) [29]. Haien ustetan, lehenengo momentuan toxinaren eta hartzaile espezifikoaren arteko lotura gertatu behar da, ondoren proteinaren domeinu hidrofobikoa mintzean txertatzeko. Behin egoera honetan, translokazio bitartekari bat osatuko litzateke eta AC domeinuak berak kaltzio $\left(\mathrm{Ca}^{2+}\right)$ ioientzako iragazkorra den aldi baterako poro bat irekiko luke [30]. Zelularen zitosolerantz sartuko diren $\mathrm{Ca}^{2+}$-ak kalpaina izeneko proteinasa bat aktibatuko luke. Kalpainak toxina-hartzaile konplexua zitoeskeletotik askatuko luke eta kolesterolean aberatsak diren lipid raft mikrodomeinuetara mugituko litzateke. Bertan translokazioaren azken pausoa gertatuko litzateke eta AC domeinua zitosolera pasatuko litzateke.

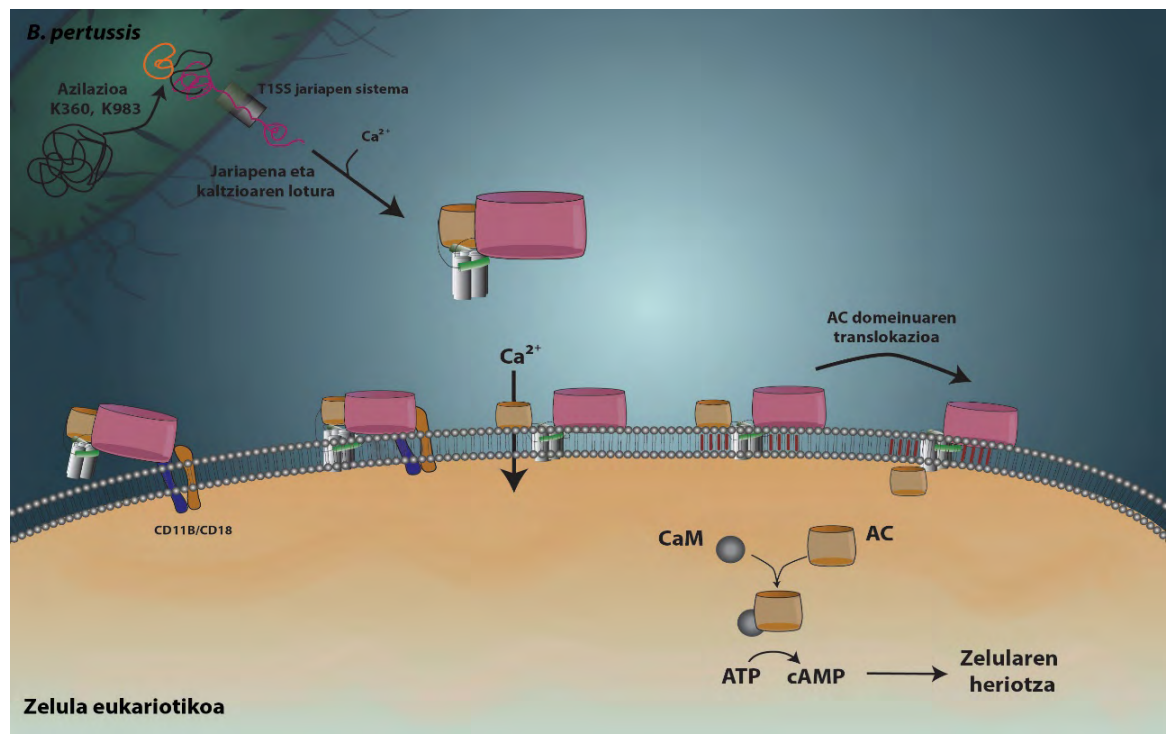

4. irudia. AC domeinuaren translokazio mekanismoa azaltzen duen eredua. AC domeinua kolore marroiz, RTX domeinua arrosaz, linker eskualdea berdez eta 5 helize hidrofobikoak grisez adierazi dira. ACTa bakterioaren barnean sintetizatzen, azilatzen eta T1SS sistemaren bidez jariatzen da. Zelulaz kanpo, RTX domeinuari $\mathrm{Ca}^{2+}$ lotuko zaio, hura tolestuz eta egonkortuz. Ondoren, RTX domeinua zelula ostalariaren CD11b/CD18 hartzaileari lotuko zaio eta domeinu hidrofobikoa mintzean txertatuko litzateke. AC domeinuak bitartekari bat osatuz, $\mathrm{Ca}^{2+}$ ioiekiko selektiboa den poro bat irekiko luke. $\mathrm{Ca}^{2+}$ fluxuak kalpaina aktibatuko luke eta kalpainak integrina eta zitoeskeletoaren arteko lotura apurtuko luke. Azkenik, toxinahartzaile konplexua lipid raft mikrodomeinuetara (gorriz adierazita) mugituko litzateke eta bertan AC domeinua zitosolean jarriko litzateke.

Hala ere, eredu honek ez du argitzen AC domeinuaren translokazio zuzena nola gertatzen den. Azken urteotan jakin da zenbait bakterio-toxinak lipidoak hidrolizatzeko gaitasuna dutela. Duela gutxi, ACTak ere fosfoli- 
Jone Amuategi Aulestiarte, Asier Benito-Vicente, Kepa B. Uribe, César Martín Plágaro, Helena Ostolaza Etxabe

pidoak hidrolizatu ditzakela deskribatu da [31]. Aipaturiko erreakzio entzimatikoaren ondorioz, lisofosfolipidoak eta gantz-azido askeak sortzen dira. Lisofosfolipidoak karbono kate bakar batez eta buru polar batez osaturiko lipido bioaktiboak dira [32] eta flip-flop mugimenduak eragin ditzakete [22], hau da, lipidoak mintzaren geruza batetik bestera mugitzea eragin dezakete (5. irudia). Mintzean lamelarrak ez diren egiturak eratzean, monogeruza lau batek kurbadura positiboa hartzen du eta ondorioz, toroide itxurako egiturak sortzen dira (6b. irudia). Hori dela eta, AC domeinuaren translokazioa toroide itxurako poro hidrofiliko batean zehar gertatuko litzakela proposatu da [33].
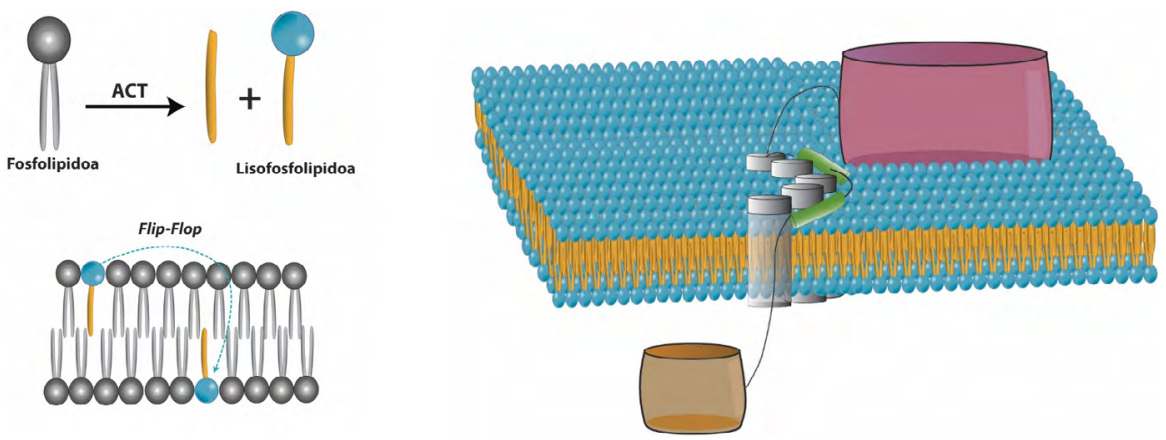

5. irudia. ACTaren fosfolipasa aktibitateak lagundutako AC domeinuaren translokazio zuzena. AC domeinua kolore marroiz, RTX domeinua arrosaz, linker eskualdea berdez eta 5 helize hidrofobikoak grisez adierazi dira. ACTaren fosfolipasa aktibitateari esker, mintzean flip-flop mugimenduak gertatzen direla eta mintza desegonkortzen dela proposatu da. Desegonkortze honetan poro toroidal bat eratuko litzateke eta $\mathrm{AC}$ domeinuak poro hidrofiliko batean zehar zuzenean gurutzatuko luke mintza.

400-500 aminoazidoen artean kokatzen den linker eskualdeari dagokionez, ezer gutxi dakigu oraindik. Hainbat $\alpha$-helizek osatzen dutela uste da eta honek, mintzarekin elkar eragiteko gaitasuna emango liokela [25]. Linker eskualdearen parte diren hondarren gehiengoa mintzean txertatzen $\mathrm{da}$, eta beraz, duela gutxi proposatu dutenez, ezinbestekoa da AC domeinua mintzean zehar garraiatu ahal izateko [34]. Izan ere, eskualde honetan kokatzen diren karga positibodun argininak mintzeko lipido anionikoei lotzen zaizkio eta AC domeinuaren translokazioa errazten omen dute [35].

\subsection{RTX domeinuaren aktibitate poro-eragilea}

ACTa Repeats in ToXins (RTX) toxina poro-eragileen familiako kidea da. Superfamilia honek aktibitate biologiko eta masa molekular desberdinak (40-600 kDa) dituzten proteinak barne hartzen ditu. Jarduerari errepa- 
ratuz gero zitotoxinak, leukotoxinak edo hemolisinak, proteasak, lipasak, bakteriozinak, zianobakterioen mugikortasunean parte hartzen duten proteinak edota oraindik funtzio ezezagunak dituzten proteinak aurki ditzakegu. Rodney A. Welchek izendatu zituen lehenengo aldiz [36] eta ordutik, bakterioen genomen sekuentziazioari esker, 1.000 RTX familia kidetik gora detektatu dira, nahiz eta gehienak karakterizatu gabe dauden oraindik [37].

a
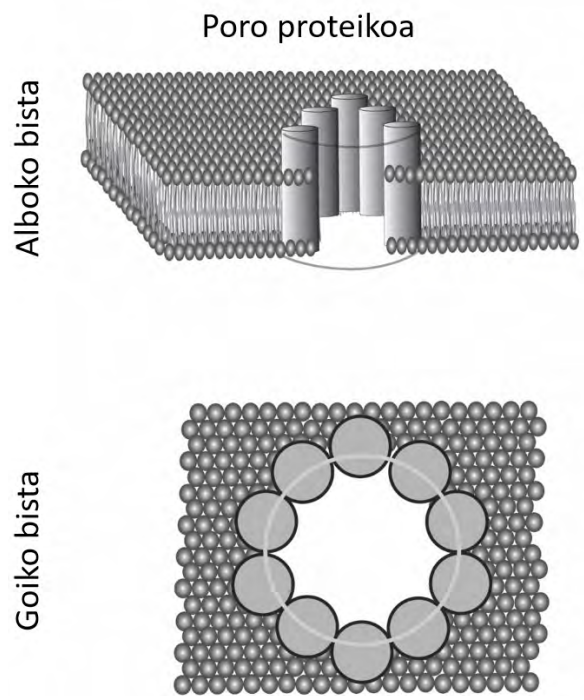

b
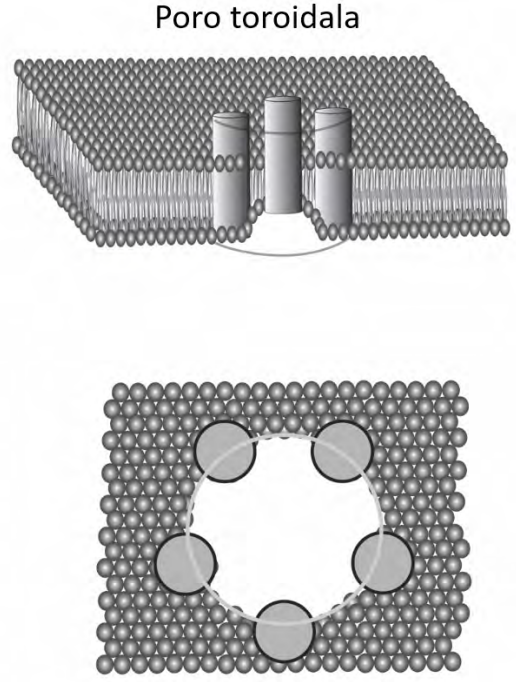

6. irudia. Mintzean eratu daitezkeen bi poro egituren eskema: (a) poro proteikoa eta (b) poro lipidiko edo toroidala. Zilindro bakoitzak proteina bakar baten domeinu poro-eragilea adierazten $\mathrm{du}$.

RTX domeinu poro-eragileak gaitasuna dauka mintzetan katioiekiko selektiboak diren poroak eratzeko eta, ondorioz, zelularen lisia eragiteko. Poro hauek hidrofilikoak dira, hau da, mintza alde batetik bestera gurutzatzen duten zulo urtsuak dira [38]. Familia bereko beste toxinen moduan, proteinak konformazio aldaketa jasaten du poroa eratzeko. Beraz, jatorriz ezkutatuta dauden eskualde hidrofobiko edota helize anfipatikoak ingurune urtsuarekin kontaktuan jartzean, $\alpha$-helizeak mintzean txertatzen dira. Horri esker, monomero nahiz oligomero (zenbait proteinaren mihiztadurak osatutako egitura) modura ere txerta daiteke. $\alpha$-itxurako poroak osatzen dituzten proteina gehienek egitura nahiko dinamikoak eratzen dituzte, normalean oligomero ez-egonkor eta ez-definituak izanik [39]. Antolakuntza molekular honetan lipidoek ere parte har dezakete eta, beraz, poro toroidalak eratzen dituztela proposatu da (6b. irudia). Hala ere, proteina hauek oli- 
Jone Amuategi Aulestiarte, Asier Benito-Vicente, Kepa B. Uribe, César Martín Plágaro, Helena Ostolaza Etxabe

gomerizaziorako erabiltzen dituzten mekanismoak guztiz argitu gabe daude oraindik.

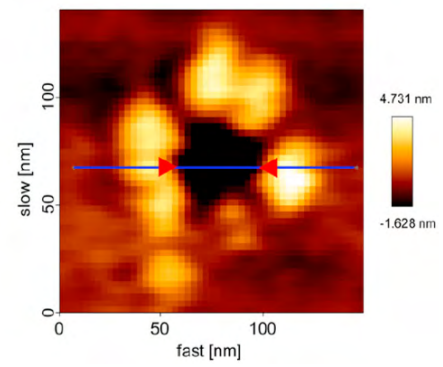

b

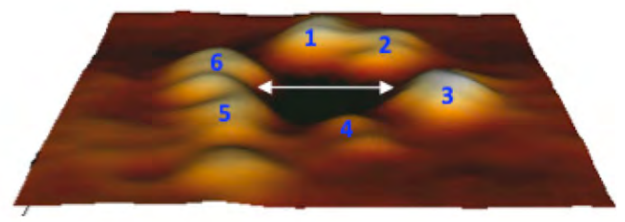

7. irudia. ACTak eratutako poro toroidalaren irudiak. (a) Indar Atomikoko Mikroskopioarekin, ingelesez Atomic Force Microscopy (AFM), ateratako irudia (goiko bista). Kolore horixkarekin ACT monomeroek osatzen duten hexameroa ageri da. Gezi gorriek mintzean zeharreko poroa adierazten dute. (b) ACTak osatutako poroaren 3 dimentsiotako (3D) AFM topografia (González-Bullón eta kideen lanetik moldatutako irudia) [40].

Laburbilduz, ACTak eragindako zelularen iragazkortzea eta lisia poro oligomeriko toroidalen bidez gertatzen dela proposatu da (7. irudia). Hasiera batean $0.6-0.8 \mathrm{~nm}$ bitarteko poro txiki proteikoak (6a. irudia) eratzen zituela uste zen arren [40] [41], azken ikerketek gauzak bestelakoak direla erakutsi dute. Hasteko, mintza hartzailedun nahiz hartzailerik gabekoetan mintzetan oligomerizatzeko gai dela frogatu da. Gainera, poroaren tamaina aldakorra dela eta doitu egin daitekeela ere ikusi da. Izatez, ACTa monomero nahiz trimero, tetramero, pentamero ala hexamero bezalako egituretan mihiztatuta aurkitu da. Honela, forma askotariko egiturak osatzeko gaitasuna izango luke: lerroak, arkuak edo eraztun itxiak, esaterako. Eratutako egituraren tamaina handituz joango litzateke inkubazio aldiaren eta toxina kontzentrazioaren arabera, tamaina anitzeko poroak eratzeko gaitasuna erakutsiz [42].

\section{PREBENTZIOA, KONTROLA ETA TRATAMENDUA}

Osasun publikoko neurriei dagokienez, gaur egun erabiltzen den kukutxeztularen aurkako neurririk eraginkorrena txertoa da [43]. Txertatze kanpainen helburu nagusia $B$. pertussis bakterioen zirkulazioa gutxitzea da, batez ere bularreko haurretan gaixotasuna ekiditeko asmoz [3].

Merkatuan aurki daitezkeen txertoen artean erabiltzen lehenak zelula osoz osatutako WCVak izan ziren. Beste txerto batzuekin alderatuz, epe luzeagorako immunitatea sortzen dute, Th1 eta Th17 T zelula laguntzai- 
leak aktibatzen dituztelako. Nazioartean erabilera zabala izan dute 1940tik gaur arte eta haiei esker gaixotasunak eragindako inpaktua eta heriotza tasa izugarri jaitsi da [44]. Merkaturatutako aukeren artean merkeena denez, mundu mailan gehien erabiltzen den prebentzio neurria da [45]. Aitzitik, zenbait kasutan, txertatu den lekuko gorriunea bezalako albo-kalte arinak eragiten dituzte eta, oso kasu bakanetan, sukarra ere eragin dezakete. Nahiz eta epe luzerako ondorio larririk ez eragin, zenbait herrialdetako txertatze programak bertan behera geratu dira, merkaturatuz joan diren txerto berriek denborarekin WCVak ordezkatu baitituzte [45].

Egungo txertoak desaktibatutako eta zelularik gabeko prestakinak dira, ingelesez Acellular Pertussis Vaccine (ACV). B. pertussisen zenbait osagai dituzte eta, beraz, babeserako erantzun immunea sortzeko gai dira. \% 80-85 inguruko eraginkortasuna dutela jotzen da [3]. Lehenengo ACVa Japonian garatu zen purifikatutako PT toxinarekin eta FHA gainazaleko proteinarekin [46]. Bigarren txertoak PT eta FHA puruagoak zituen, hainbat kontzentrazio eta konbinaziotako beste antigeno batzuekin nahasturik [47]. ACVek eragindako albo-kalteak arinagoak dira, erreakzioren bat eragin dezaketen osagaiak, lipopolisakaridoa adibidez, purifikazioan zehar baztertzen baitira. Baina Th2 T zelula laguntzaileen bidezko erantzun humorala bakarrik eragiten dutenez, eragindako immunitatea laburragoa izaten da.

Gaur egun kukutxeztularen aurka erabiltzen diren txertoak txerto batzuen arteko konbinazioak dira; izan ere, beste gaixotasun batzuekiko immunitatea eskaintzen duten osagaiekin konbinatzen dira. 1948an merkaturatu zen tetanos toxoidearekin eta difteria toxoidearekin nahastutako WCVan (DTP txertoan) oinarritzen dira, baina honek baino albo-kalte txikiagoak eragiten dituzte [45].

Biztanleriaren \% 95 inguruk txertoa jaso duen arren, azken urteotan kukutxeztul kasuen igoera nabarmena erregistratu da hainbat herrialdetan. Arnasbideetako beste patogeno batzuek ez bezala, B. pertussisi lotutako agerraldiak ez dira uniformeak izaten, ez baitaude urtaroei edota leku zehatzei loturik. Gainera, 3-5 urtean behin, ziklikoki kutsatu kopuruak gora egiten du [2]. Gorakada garapen bidean dauden herrialdeetan nahiz herrialde garatuetan gertatzen denez, OMEk gaixotasunaren gorakada mundu mailan gertatzen ari dela onartu behar izan du [48]. B. pertussisen aurkako immunitatea behin-behinekoa izateak eragin ditzake gorakada zikliko hauek. Izan ere, aipaturiko immunitatea ez da betiko izaten, ez prozesu naturaletan ezta txerto bidezkoetan ere. Kukutxeztularekiko immunitate naturalak 3,5-30 urte arteko eraginkortasuna daukala kalkulatzen da; WCV bidez eskuratutakoak 5-14 urte artekoa; eta ACV bidezkoak 4-7 urte artekoa. Ondorioz, immunitatea denbora pasa ahala gutxituz doa eta oso ohikoa da berriro gaixotzea. Halere, gaixotasunaren larritasunak immunitatea eskuratu zen unetik pasatako denborarekin harreman zuzena du [49]. Behin-behineko immunitateaz gain, errefortzuko 
Jone Amuategi Aulestiarte, Asier Benito-Vicente, Kepa B. Uribe, César Martín Plágaro, Helena Ostolaza Etxabe

txertorik ez egoteak, diagnosi metodoen hobekuntzak edota organismoak jasan ditzakeen aldaketa genetikoek ere eragina izan dezakete gorakada hauetan [44].

Tamalez, aurretiaz aipaturiko arrazoiek zaildu egiten dute kukutxeztula kontrolpean izatea. Kukutxeztularen epidemiologia hobeto ulertzeko eta gaixotasunaren kontrola optimizatzeko mundu mailako zainketa hobetu behar da ezinbestez. Europa mailan, gaixotasunen zaintza eta kontrolerako erakundeak, ingelesez European Centre for Disease Prevention and Control (ECDC), kukutxeztularen inguruko ezagutza eta praktikak hobetzeko bi sare finantzatzen ditu: EUPert-LabNet (European Laboratory Network for Pertussis) eta PERTINENT (Pertussis in Infants European Network). EUPert-LabNet sarea diagnosi-metodoen estandarizazioa sustatzeaz eta ospitaleetako langileen formakuntzaz arduratzen da. PERTINENT sarea 2015ean sortu zen eta 6 estatutako 37 ospitale zelatari biltzen ditu. Ospitaleratuta dauden haurren zaintza aktiboa hobetzeko sortu zen, batez ere, kukutxeztularen eragina, larritasuna, arrisku-faktoreen identifikazioa eta txertoaren eraginkortasuna neurtzeko asmoz [50].

Munduko beste hainbat lekutan bezala, EAEn ere prebentzio kanpaina eraginkorrak jarri nahi izan dira martxan. Izan ere, 2015ean Espainian kukutxeztul kasu gehien erregistratu zituen autonomia erkidegoa izan zen, 1.977 kasurekin. Osakidetzaren prebentzio kanpainak 3 ardatz dauzka helburutzat: lehenik, detekzioa, ikerkuntza eta agerraldien kontrola; bigarrenik, gaixotasunaren patroi epidemiologikoen eta arrisku-taldeen identifikazioa; eta hirugarrenik, txertatze programak epidemiologian duen eraginaren azterketa. Detekzio metodoei dagokienez, alde batetik irizpide klinikoak zehazten dira, helduetan ondorengo sintomen bilaketan zentratuko direnak: gutxienez 2 astez eztul paroxistikoa izatea, arnasa hartzean soinu bizia ateratzea edota eztulak eraginda oka egitea. Urte batetik beherako haurrek, berriz, apnea ere izan dezakete. Bestetik, laborategiko irizpideei dagokienez, lagin klinikoetan $B$. pertussisen azido nukleikoa detektatu, hura isolatu edo haren aurkako antigorputz espezifikoak detektatu behar dira. Azido nukleikoaren detekziorako gehien erabiltzen den teknika Polymerase Chain Reaction (PCR) izenekoa da. Azkenik, irizpide epidemiologikoei dagokienez, laborategian baieztatutako positibo batekin sintomen aurreko 6-20 egun bitartean kontaktua izan duten banakoak kutsatutzat hartzen dira. 3 irizpide mota sailkatu ditugun arren, laborategiko proba da ezinbestekoa kasu bat baieztatzeko [3].

Jakina da pertsonarik zaurgarrienak jaioberriak direla, batez ere, txertoa jasotzeko aukerarik izan ez duten urte bat baino gutxiagoko haurrak. Beraz, txertatze kanpainei dagokienez, EAEn haurdunaldiaren hirugarren hiruhilekoan (ahal dela 27-31 asteen artean) karga baxuko txerto konbinatu bat ematen da. Garai honetan jasotzen du fetuak antigorputz transferentziarik handiena eta, honela, jaioberria bizitzako lehen asteetarako babestea 
lortzen da [2]. Honez gain, 2017 aurretik jaiotako haurrek 2, 4, 6 eta 18 hilabete dituztenean karga altuko DTP txerto bana jasotzen dute. Gainera, 6 urte betetzen dituztenean karga baxuko oroimen-dosi bat (dTpa txertoa) jasotzen dute. Aldiz, 2017tik aurrera jaiotako haurrentzat kanpaina aldatu egin da. Orain 2, 4 eta 11 hilabete dituztenean jasotzen dute karga altuko DTP txertoa eta 6 urterekin jasotzen duten oroimen-dosia desberdina da (DTPa-VPI txertoa). Era berean, pediatriako eta obstetriziako langileei ere karga baxuko txertoa jasotzea gomendatzen zaie azken 5 urteetan jaso ez badute. EAEn 2004tik kukutxeztularen aurka eskaintzen diren txerto guztiak zelularik gabekoak dira eta txertatze kanpainak \% 90eko estaldura du, hau da, jaioberrien \% 90ek jasotzen du [3].

Gaixotasuna kontrolpean mantendu ahal izateko kutsatzeak ekiditea ezinbestekoa da. Garrantzitsuena bularreko haurren kutsatzea saihestea da, batez ere, lehenengo txerto seriea jaso ez dutenena. Horretarako, kasu susmagarriak nahiz baieztatutakoak isolatu egiten dira antibiotiko bidezko tratamendua hasi eta 5 egun pasa arte. Antibiotikorik jasotzen ez duten pertsonek, berriz, sintomak agertu eta ondorengo 21 egunetan gutxienez isolaturik egon behar dute [3]. Tratamenduaren helburu nagusia bakterioa nasofaringetik kanporatzea da, eta horretarako, medikuak aginduta, gutxienez 5 eguneko antibiotiko tratamendua jaso behar da. Tratamendua eztula hasi eta lehenengo 3 asteetan (katarro fasean) hastea gomendatzen da, sintomak arindu eta bakterioa desagerrarazteko, baina, zoritxarrez, gutxitan hasten da garaiz. Medikuak gaixoaren adina, medikamenturen baten aurkako erantzunik izan duen, tolerantzia, kostua etab. kontuan izan behar ditu antibiotikoa hautatu aurretik. Kasu honetan antibiotiko arrunten (anpizilina, zefalosporina, tetraziklina, kloranfenikola eta fluorokinolona) eraginkortasuna txikia denez, antibiotiko makrolidoak erabiltzen dira. Horien artean eritromizina, klaritromizina edo azitromizina aurki ditzakegu, besteak beste. Halere, urte batetik beherako haurrentzat soilik azitromizina gomendatzen da [2]. B. pertussisen zenbait anduik zenbait antibiotikoekiko erresistentzia garatu dutela frogatu den arren, makrolidoekiko erresistentzia oso txikia da (\% 1 baino txikiagoa) [51]. Hala ere, garrantzitsua da behatutako erresistentzia hauen jarraipena egitea, batez ere makrolidoak huts egiten ari diren eremuetan.

\section{ONDORIOAK}

$B$. pertussisek eragindako infekzioak gaixotasun larriak eragin ditzake eta ondorioz, kostu zuzenak eta zeharkakoak handiak dira. Kukutxeztulari lotutako kostu soziala nerabe eta heldu bakoitzeko 800-1950 \$ artean dagoela uste da [52].

3-5 urtean behin errepikatzen diren agerraldiek argi utzi dute gaixotasun hau ez dagoela guztiz kontrolpean, ez garapen bidean dauden herrial- 
Jone Amuategi Aulestiarte, Asier Benito-Vicente, Kepa B. Uribe, César Martín Plágaro, Helena Ostolaza Etxabe

deetan ezta herrialde garatuetan ere. Martxan dauden immunizazio kanpainak indartsuak diren arren, gaur egun merkatuan aurki daitezkeen txertoak ez dira guztiz eraginkorrak. Hori ikusirik eta gaixotasunaren gorakadaren aurrean, txertoak eta immunizaziorako tresna berriak garatzeko beharra itzuli da [53], esaterako: hobetutako ACVak, toxikotasun txikiagoko WCVak eta kanpo mintzeko besikuletan oinarritutako txertoak. Sendagai berrientzako itu zelularrak identifikatu nahi badira, bakterioak baliatzen dituen mekanismo infekziosoetan arreta jarri beharko da. Itu horietako bat ACTa izan daiteke, hari buruzko ikerketan emandako aurrerapausoek ikuspegi berriak zabaldu baitituzte. Esaterako, azken bi hamarkadetan jasotako datuei esker ACTa txerto garraiatzaile eraginkorra eta moldakorra izan litekela jakin dugu. AC domeinuaren antzeko polipeptidoak ere gehitu dakizkioke, zelula eukariotoak erasotzeko daukan gaitasuna galdu gabe. Hortaz, intereseko antigenoak erantzun immunean parte hartzen duten zeluletara bideratu ahalko lirateke. Gainera, toxina honen ezagutzak itu molekularra izatetik haratago, zelularen mintzean zehar gertatzen diren beste hainbat prozesu ulertzen ere lagundu dezake.

Horrek guztiak, berriro ere, oinarrizko ikerkuntzan nahiz ikerkuntza aplikatuan egin beharko litzatekeen inbertsioa handitzea eskatzen du. Zorionez, orain, hainbat diziplinatako tresna berriak konbinatu daitezke kukutxeztula mundu mailan kontrolpean mantendu ahal izateko. Alde batetik, animalia ereduak patogenesia ulertzeko oinarrizkoak izan dira. Baina, horrez gain, diziplina anitzen arteko lankidetzak funtsezkoak izango dira mundu osoko herrietan zehar dabiltzan anduien identifikaziorako eta haien bilakaera ulertzeko. Honela, gaixotasunaren gorakadarekin lotzen diren ingurumen-faktoreak, faktore ekologikoak eta gizakiarekin zerikusia dutenak (antibiotikoen erabilera, txertoak, immunitatea, portaera...), identifikatu ahal izango dira [2].

\section{ESKER ONAK}

Artikulu hau Jone Amuategiri esleitutako UPV/EHUren Doktorego Tesirako beka bati esker eta Helena Ostolazak jasotako Espainiako Ekonomia eta Lehiakortasun Ministerioko (BFU2017-82758-P (AEI/FEDER, UE) eta Eusko Jaurlaritzako (Grupos Consolidados IT1264-19) dirulaguntzei esker idatzi da.

\section{BIBLIOGRAFIA}

[1] The top 10 causes of death, World Health Organization (WHO): https:// www.who.int/es/news-room/fact-sheets/detail/the-top-10-causes-of-death (2020-04-27). 
[2] KILGORE, P.E., SALIM, A.M., ZERVOS, M.J., eta SCHMITT, H.J. 2016. «Pertussis: Microbiology, Disease, Treatment, and Prevention». Clin. Microbiol. Rev., 29, 449-486.

[3] Tosferina. Adaptación de los protocolos de la Red Nacional de Vigilancia Epidemiológica (RENAVE), Osakidetza: https://www.osakidetza. euskadi.eus/contenidos/informacion/vigilancia_protocolos/es_def/adjuntos/ Tosferina_cast_01-03-18.pdf (2020-04-27).

[4] DAUGHTRY-DENMARK, L. 1936. «Studies in Whooping Cough». J. Dis. Child., 52(3), 587-598.

[5] European Centre for Disease Prevention and Control (ECDC): https:// www.ecdc.europa.eu/en/publications-data/pertussis-annual-epidemiologicalreport-2017 (2020-05-07).

[6] ARGONDIZO-CORREIA, C., RODRIGUES, A.K.S., eta DE BRITO, C.A. 2019. «Neonatal Immunity to Bordetella pertussis Infection and Current Prevention Strategies». J. Immunol. Res., 2019, 1-10.

[7] BORDET, J., eta GENGOU, O. 1906. «Le Microbe de la Coqueluche». Les Ann. l'Institut Pasteur, 20, 731-741.

[8] HOFFMAN, C.L., GONYAR, L.A., ZACCA, F., SISTI, F., FERNANDEZ, J., WONG, T., DAMRON, F.H., eta HEWLETT, E.L. 2019. «Bordetella pertussis Can Be Motile and Express Flagellum-Like Structures». MBio., 10, e00787-19.

[9] MOON, K., BONOCORA, R.P., KIM, D.D., CHEN, Q., WADE, J.T., STIBITZ, S., eta HINTON, D.M. 2017. «The BvgAS regulon of Bordetella pertussis». MBio., 8 (5) e01526-17.

[10] MELVIN, J.A., SCHELLER, E. V., MILLER, J.F., eta COTTER, P.A. 2014. «Bordetella pertussis pathogenesis: Current and future challenges». Nat. Rev. Microbiol., 12, 274-288.

[11] HEGERLE, N., eta GUISO, N. 2014. «Bordetella pertussis and pertactin-deficient clinical isolates: Lessons for pertussis vaccines». Expert Rev. Vaccines, 13, 1135-1146.

[12] BRUMMELMAN, J., WILK, M.M., HAN, W.G.H., VAN ELS, C.A. eta MILLS, K.H 2015. «Roads to the development of improved pertussis vaccines paved by immunology». Pathog. Dis., 73, ftv067.

[13] Merriam-Webster Dictionary: https://www.merriam-webster.com/dictionary/ toxin\#note-1 (2020-05-07)

[14] Biology Dictionary: https://biologydictionary.net/toxin/ (2020-05-07)

[15] Dorland's Medical Dictionary: https://web.archive.org/ web/20090628224336/http://www.mercksource.com/pp/us/cns/cns hl_dorlands_split.jsp?pg=/ppdocs/us/common/dorlands/dorland/ eight/000109718.htm (2020-04-27)

[16] DORJI, D., MOOI, F., YANTORNO, O., DEORA, R., GRAHAM, R.M., eta MUKKUR, T.K. 2018. «Bordetella pertussis virulence factors in the continuing evolution of whooping cough vaccines for improved performance». Med. Microbiol. Immunol. 207, 3-26. 
Jone Amuategi Aulestiarte, Asier Benito-Vicente, Kepa B. Uribe, César Martín Plágaro, Helena Ostolaza Etxabe

[17] FEDELE, G., BIANCO, M., eta AUSIELLO, C.M. 2013. «The virulence factors of Bordetella pertussis: Talented modulators of host immune response». Arch. Immunol. Ther. Exp. 61, 445-457.

[18] CHENAL, A. 2018. "An Introduction to the Toxins Special Issue on the Adenylate Cyclase Toxin». Toxins, 10, 386.

[19] HANSKI E eta FARFEL Z. 1985. «Bordetella pertussis invasive adenylate cyclase. Partial resolution and properties of its cellular penetration». J Biol Chem, 260 (9), 5526-5532.

[20] EBY, J. C., HOFFMAN, C. L., GONYAR, L. A. eta HEWLETT, E. L. 2015. «Review of the neutrophil response to Bordetella pertussis infection». Pathogens and disease, 73 (9), fttv081.

[21] ROGEL, A., eta HANSKI, E. 1992. «Distinct steps in the penetration of adenylate cyclase toxin of Bordetella pertussis into sheep erythrocytes. Translocation of the toxin across the membrane». J. Biol. Chem. 267, 22599-22605.

[22] MARTIN, C., REQUERO, M.A., MASIN, J., KONOPASEK, I., GOÑI, F.M., SEBO, P., eta OSTOLAZA, H. 2004. «Membrane Restructuring by Bordetella pertussis Adenylate Cyclase Toxin, a Member of the RTX Toxin Family». J. Bacteriol., 186, 3760-3765.

[23] GUERMONPREZ, P., KHELEF, N., BLOUIN, E., RIEU, P., RICCIARDI-CASTAGNOLI, P., GUISO, N., LADANT, D., eta LECLERC, C. 2001. «The adenylate cyclase toxin of Bordetella pertussis binds to target cells via the $\alpha \mathrm{M} \beta 2$ integrin (CD11b/CD18)».J. Exp. Med., 193, 1035-1044.

[24] PACCANI, S.R., FINETTI, F., DAVI, M., PATRUSSI, L., D’ELIOS, M.M., LADANT, D., eta BALDARI, C.T. 2011. «The Bordetella pertussis adenylate cyclase toxin binds to T cells via LFA-1 and induces its disengagement from the immune synapse». J. Exp. Med. 208, 1317-1330.

[25] SUBRINI, O., SOTOMAYOR-PÉREZ, A.-C., HESSEL, A., SPIACZKAKARST, J., SELWA, E., SAPAY, N., VENEZIANO, R., PANSIERI, J., CHOPINEAU, J., LADANT, D., eta CHENAL, A. 2013. «Characterization of a Membrane-active Peptide from the Bordetella pertussis CyaA Toxin». J. Biol. Chem., 288, 32585-32598.

[26] MASIN, J., OSICKOVA, A., SUKOVA, A., FISER, R., HALADA, P., BUMBA, L., LINHARTOVA, I., OSICKA, R., eta SEBO, P. 2016. «Negatively charged residues of the segment linking the enzyme and cytolysin moieties restrict the membrane-permeabilizing capacity of adenylate cyclase toxin». Sci. Rep., 6, 29137.

[27] HEWLETT, E., eta WOLFF, J. 1976. «Soluble adenylate cyclase from the culture medium of Bordetella pertussis: purification and characterization». J. Bacteriol., 127, 890-898.

[28] WOLFF, J., COOK, G.H., GOLDHAMMER, A.R., eta BERKOWITZ, S.A. 1980. «Calmodulin activates prokaryotic adenylate cyclase». Proc. Natl. Acad. Sci., 77, 3841-3844.

[29] BUMBA, L., MASIN, J., FISER, R., eta SEBO, P. 2010. «Bordetella Adenylate Cyclase Toxin Mobilizes Its $\beta 2$ Integrin Receptor into Lipid Rafts 
Kukutxeztula: «gainditutako» gaitz baten itzulera

to Accomplish Translocation across Target Cell Membrane in Two Steps». PLoS Pathog., 6, e1000901.

[30] FISER, R., MASIN, J., BASLER, M., KRUSEK, J., SPULAKOVA, V., KONOPASEK, I., eta SEBO, P. 2007. «Third Activity of Bordetella Adenylate Cyclase (AC) Toxin-Hemolysin». J. Biol. Chem., 282, 2808-2820.

[31] GONZÁLEZ-BULlÓN, D., B. URIBE, K., MARTÍN, C. eta OSTOLAZA, H. 2017. «Phospholipase A activity of adenylate cyclase toxin mediates translocation of its adenylate cyclase domain». Proc. Natl. Acad. Sci. 114, E6784-E6793.

[32] Encyclopedia of Molecular Pharmacology, Springer: https://link.springer. com/referenceworkentry/10.1007\%2F978-3-540-38918-7_90 (2020-05-08).

[33] GONZÁlEZ-BULlÓN, D., B. URIBE, K., LARGO, E., GUEMBELZU, G., GARCÍA-ARRIBAS, A.B., MARTÍN, C., eta OSTOLAZA, H. (2019). «Membrane Permeabilization by Bordetella Adenylate Cyclase Toxin Involves Pores of Tunable Size». Biomolecules, 9, 183.

[34] KARST, J.C., BARKER, R., DEVI, U., SWANN, M.J., DAVI, M., ROSER, S.J., LADANT, D., eta CHENAL, A. 2012. «Identification of a region that assists membrane insertion and translocation of the catalytic domain of Bordetella pertussis CyaA toxin». J. Biol. Chem., 287, 9200-9212.

[35] MASIN, J., OSICKOVA, A., SUKOVA, A., FISER, R., HALADA, P., BUMBA, L., LINHARTOVA, I., OSICKA, R., eta SEBO, P. 2016. «Negatively charged residues of the segment linking the enzyme and cytolysin moieties restrict the membrane-permeabilizing capacity of adenylate cyclase toxin». Sci. Rep., 6, 29137.

[36] WELCH, R.A. 1991. «Pore-forming cytolysins of Gram-negative bacteria». Mol. Microbiol., 5, 521-528.

[37] LINHARTOVA, I., BUMBA, L., MASIN, J., BASLER, M., OSICKA, R., KAMANOVA, J., PROCHAZKOVA, K., ADKINS, I., HEJNOVA-HOLUBOVA, J., SADILKOVA, L., et al. 2010. «RTX proteins: A highly diverse family secreted by a common mechanism». FEMS Microbiol.Rev., 34, 1076-1112.

[38] FRADIN, C., SATSOURA, D., eta ANDREWS, D.W. 2009. «Punching Holes in Membranes: How Oligomeric Pore-Forming Proteins and Lipids Cooperate to Form Aqueous Channels in Membranes». Biomembrane Frontiers: Nanostructures, Models and, the Design of Life, Handbook of Modern Biophysics, 223-262. Springer, Suiza.

[39] ANDERLUH, G., eta LAKEY, J.H. 2008. «Disparate proteins use similar architectures to damage membranes». Trends Biochem. Sci., 33, 482-490.

[40] BENZ, R., MAIER, E., LADANT, D., ULLMANN, A., eta SEBO, P. 1994. «Adenylate cyclase toxin (CyaA) of Bordetella pertussis. Evidence for the formation of small ion-permeable channels and comparison with HlyA of Escherichia coli». J. Biol. Chem., 269, 27231-27239.

[41] SZABO, G., GRAY, M.C., eta HEWLETT, E. 1994. «Adenylate cyclase toxin from Bordetella pertussis produces ion conductance across artificial li- 
Jone Amuategi Aulestiarte, Asier Benito-Vicente, Kepa B. Uribe, César Martín Plágaro, Helena Ostolaza Etxabe

pid bilayers in a calcium- and polarity-dependent manner». J. Biol. Chem., 269, 22496-22499.

[42] Centers for Disease Control and Prevention (CDC): https://www.cdc.gov/ pertussis/about/prevention/index.html (2020-05-13).

[43] BISGARD, K.M., RHODES, P., CONNELLY, B.L., BI, D., HAHN, C., PATRICK, S., GLODÉ, M.P., eta EHRESMANN, K.R. 2005. «Pertussis vaccine effectiveness among children 6 to 59 months of age in the United States, 1998-2001». Pediatrics, 116(2), 285-94.

[44] TAN, T., DALBY, T., FORSYTH, K., HALPERIN, S.A., HEININGER, U., HOZBOR, D., PLOTKIN, S., ULLOA-GUTIERREZ, R., eta VON KÖNIG, C.H.W. 2015. «Pertussis Across the Globe: Recent Epidemiologic Trends From 2000 to 2013». Pediatr. Infect. Dis. J., 34, 222-232.

[45] MARKEY, K., ASOKANATHAN, C., eta FEAVERS, I. 2019. «Assays for Determining Pertussis Toxin Activity in Acellular Pertussis Vaccines». Toxins, 11, 417.

[46] SATO, Y., KIMURA, M., eta FUKUMI, H. 1984. «Development of a Pertussis component vaccine in Japan». Lancet, 323, 122-126.

[47] RAPPULI, R., PODDA, A., PIZZA, M., COVACCI, A., BARTOLONI, A., DE MAGISTRIS, M.T., eta NENCIONI, L. 1992. «Progress towards the development of new vaccines against whooping cough». Vaccine, 10, 10271032.

[48] Pertussis, WHO: https://www.who.int/immunization/diseases/pertussis/en/ (2020-05-20).

[49] WEARING, H.J., eta ROHANI, P. 2009. «Estimating the duration of pertussis immunity using epidemiological signatures». PLoS Pathog., 5(10), e1000647.

[50] Pertussis. Annual Epidemiological Report for 2017, ECDC: https://www. ecdc.europa.eu/sites/default/files/documents/AER_for_2017-pertussis.pdf (2020-05-14).

[51] WILSON, K.E., CASSIDAY, P.K., POPOVIC, T., eta SANDEN, G.N. 2002. «Bordetella pertussis isolates with a heterogeneous phenotype for erythromycin resistance». J. Clin. Microbiol. 40, 2942-2944.

[52] LEE, G.M., LETT, S., SCHAUER, S., LEBARON, C., MURPHY, T.V., RUSINAK, D., eta LIEU, T.A. 2004. "Societal Costs and Morbidity of Pertussis in Adolescents and Adults». Clin. Infect. Dis. 39, 1572-1580.

[53] CARBONETTI, N.H. 2016. Bordetella pertussis: «New concepts in pathogenesis and treatment». Curr. Opin. Infect. Dis. 29, 287-294. 